\title{
A framework for estimating pollutant export coefficients from long-term in-stream water quality monitoring data
}

\author{
S. Shrestha ${ }^{\mathrm{a}, *}$, F. Kazama ${ }^{\text {a }}$, L.T.H. Newham ${ }^{\mathrm{b}}$ \\ ${ }^{a}$ Interdisciplinary Graduate School of Medicine and Engineering, University of Yamanashi, 4-3-11 Takeda, \\ Kofu, Yamanashi 400-8511, Japan \\ ${ }^{\mathrm{b}}$ Integrated Catchment Assessment and Management Centre, The Fenner School of Environment and Society, The Australian National University, \\ Building 48A Linnaeus Way, Canberra, ACT 0200, Australia
}

Received 18 January 2007; received in revised form 9 May 2007; accepted 11 May 2007

Available online 3 July 2007

\begin{abstract}
Modeling techniques for estimating pollutant loadings to water bodies range from simple export coefficient and regression models to more complex mechanistic models. All export coefficient models and many complex mechanistic models rely on pollutant export coefficients to estimate pollution sources and transport in large watersheds. Typically, pollutant export coefficients are determined by monitoring small catchments or field plots to isolate individual landuse contributions. However, pollutant export coefficients derived from small catchment and field plot scale studies cannot be confidently used in catchment-scale water quality modeling. The objective of this paper is to present a framework to estimate the export coefficients of pollutants from commonly available in-stream water quality monitoring data. A combination of readily and freely available statistical, spatial and hydrological tools and a multiple regression methodology is proposed to estimate pollutant export coefficients. A case study from the Fuji River catchment, Japan is presented where export coefficients of organic matters and nutrients are estimated. Most of the estimated pollutant export coefficients are significant at $\alpha$ equal to 0.05 and the landuse categories used in the multiple regression models explained more than $85 \%$ variability in loadings. These results are encouraging especially given the pressing need to identify appropriate management practices to improve the water quality within the catchment. It is recommended to investigate further the required number of water quality monitoring stations, sampling frequencies and sampling duration of water quality constituents to enhance the robustness and usefulness of the proposed methodology.
\end{abstract}

(C) 2007 Elsevier Ltd. All rights reserved.

Keywords: Water quality; Pollutant export coefficients; Point and non-point source pollutant loadings; $\mathrm{BOD} ; \mathrm{COD}_{\mathrm{Mn}} ; \mathrm{NO}_{3}-\mathrm{N} ; \mathrm{PO}_{4}-\mathrm{P}$

\section{Introduction}

Excessive loading of organic matter and nutrients into rivers, lakes, reservoirs and estuaries is of a major concern to water resources managers. These problems not only include eutrophication that leads to a significant loss of amenity in terms of water supply, fisheries and recreation (ICWE, 1992), but also increases water treatment costs (Howarth et al., 2000). Generally, two types of sources of pollution are defined. The first is point source pollution that can be traced

\footnotetext{
* Corresponding author. Tel./fax: +81 552208193.

E-mail address: sangam@yamanashi.ac.jp (S. Shrestha).
}

back to a single origin or source such as a sewage treatment plant discharge. Point sources are relatively easy to identify, quantify and control (Carpenter et al., 1998). The second is non-point sources that are driven by multiple factors and includes diffuse pollution which is exclusively a result of human landuse and landuse changes (Novotny, 1999). Nonpoint source pollution cannot be traced back to a single origin or source such as storm-water runoff, water runoff from urban areas or failed septic systems.

For effective water quality management, it is important to assess changes in input loads rather than concentrations. For regulatory purposes, it is difficult to assess compliance based on concentration data alone. The loads are the only 
scientifically robust measure of the effectiveness of remediation. This approach is reflected in the development of the concept of Total Maximum Daily Loads (TMDL) (Novotny, 2003). Therefore, it is necessary to identify and quantify the sources of pollution to develop control efforts such as developing the concept of TMDL.

A large number of water quality models have been developed to estimate the pollution loadings into the water bodies. These models range from simple export coefficient models (Beaulac and Reckhow, 1982; Johnes, 1996); regression models such as SPARROW (Alexander et al., 2002), ESTIMATOR (Cohn et al., 1992) to complex mechanistic models such as CREAMS (Knisel, 1980), ANSWERS (Beasley et al., 1980), GLEAMS (Leonard et al., 1987), WEPP, AGNPS (Young et al., 1989), HSPF (Donigian et al., 1995), SWAT (Arnold and Allen, 1996), CatchMODS (Newham et al., 2004), IWRAM DSS (Cuddy et al., 2005), LSPC (Shen et al., 2005), MONERIS GREAT-ER; Elbe-DSS (Matthies et al., 2006). Similarly, some models have been applied successfully to assess the catchment condition and evaluate the alternative management practices to reduce the point and non-point source pollution (for e.g. Alp and Cigizoglu, 2007; Polyakov et al., in press; Santhi et al., 2006; Shrestha et al., 2006; Yeh et al., 2006; Yuan et al., 2007).

All export coefficient models and some complex mechanistic models rely on generally landuse-based export coefficients to estimate organic matters, nutrient sources and nutrient transport in large watersheds (Beaulac and Reckhow, 1982). Pollutant export coefficients, representing the rate of pollutant loadings by land area, are often recommended as a way to estimate loadings from non-point sources (Loehr et al., 1989; Reckhow et al., 1980). However, the use of pollutant export coefficients for estimating pollution loads is based on the knowledge that, for a given climatological regime, specific landuse types will yield or export characteristic quantities of pollutants to a downstream water body over an annual cycle or longer term (Rast and Lee, 1983). Therefore, it is necessary to develop regionally or locally specific pollutant export coefficients to estimate the pollutant loadings into water bodies.

Typically, pollutant export coefficients are determined by monitoring pollutant exports from small catchments with a predominant landuse or by using field plots to isolate individual landuses (Reckhow et al., 1980). There are several issues in developing pollutant export coefficients by field plot studies and using them to estimate pollution loadings at larger scales. The first and most important issue is the difficulty of identifying and monitoring pollutant fluxes for catchments containing a single homogenous landuse type (McFarland and Hauck, 2001). Organic matter and nutrient export estimates are often based on watersheds on the order of $10^{2}$ to $10^{4}$ hectares (Fisher et al., 1998). Watersheds in this size range are usually nested upstream or downstream components of larger drainage catchments (Wickham et al., 2003). These export coefficients do not represent the average of conditions and practices (e.g., soils, planting and harvest dates, fertilization timing and amounts, slopes, tillage practices, and proximity to streams) within the entire catchment. This necessitates greater effort in determining pollutant export coefficients and may result in larger uncertainties in load estimation.

A second important issue in developing pollutant export coefficients is the time and budget constraints on monitoring water quality at larger spatial and longer temporal scales. This is needed in order to capture the spatial and temporal variability of catchment processes. A final consideration is gaining access to continuous streamflow data to estimate loadings for developing pollutant export coefficients. Fortunately with increasing concern over environmental issues, many countries have already established monitoring programs to assess the magnitude and consequences of human stresses on the environment. This includes routine data collection (e.g. weekly, fortnightly, monthly, seasonally), often carried out by local authorities for resource assessment and state of environment reporting. It is important that monitoring effort is exploited to the fullest extent for optimal use of the limited resources available (Lophaven et al., 2006).

The broad objective of this paper is therefore to provide a framework to estimate the pollutant export coefficients from long-term in-stream water quality monitoring data sets. The proposed framework is discussed in Section 2. It describes the selection of water quality monitoring stations, catchment subdivision, determination of major landuse areas above monitoring stations, estimation of discharge at ungauged sites within a catchment, loading estimation methods and methods to determine optimal estimates of pollutant export coefficients from major landuses. In Section 3, a case study is carried out in Fuji River catchment of Japan to demonstrate the ability of the proposed methodology to estimate export coefficients of selected water quality constituents. Finally, the results obtained from applying the methodology are discussed.

\section{Framework}

The framework presented here to estimate pollutant export coefficients involves the use of readily and freely available spatial, statistical tools and datasets. The estimation procedure starts with selection of water quality monitoring stations. Regression modeling to estimate loadings of organic matters and nutrients into a river system follows. Fig. 1 shows the framework proposed for estimating pollutant export coefficients.

\subsection{Selection of water quality monitoring stations}

For the estimation of pollutant export coefficients, sampling stations located in major tributaries are useful to enable disaggregation of the whole catchment into sub-catchments. In some cases, the sampling stations are influenced by adjacent point sources, the effects of which are often difficult to separate from non-point sources. The sampling stations which are heavily influenced by point sources should be excluded from further analysis. In general, 30 or more sampling sites are necessary to provide adequate power to the regression analysis approach of estimating pollutant export coefficients (McFarland and Hauck, 2001). However, the maximum number of sites available should be used. 


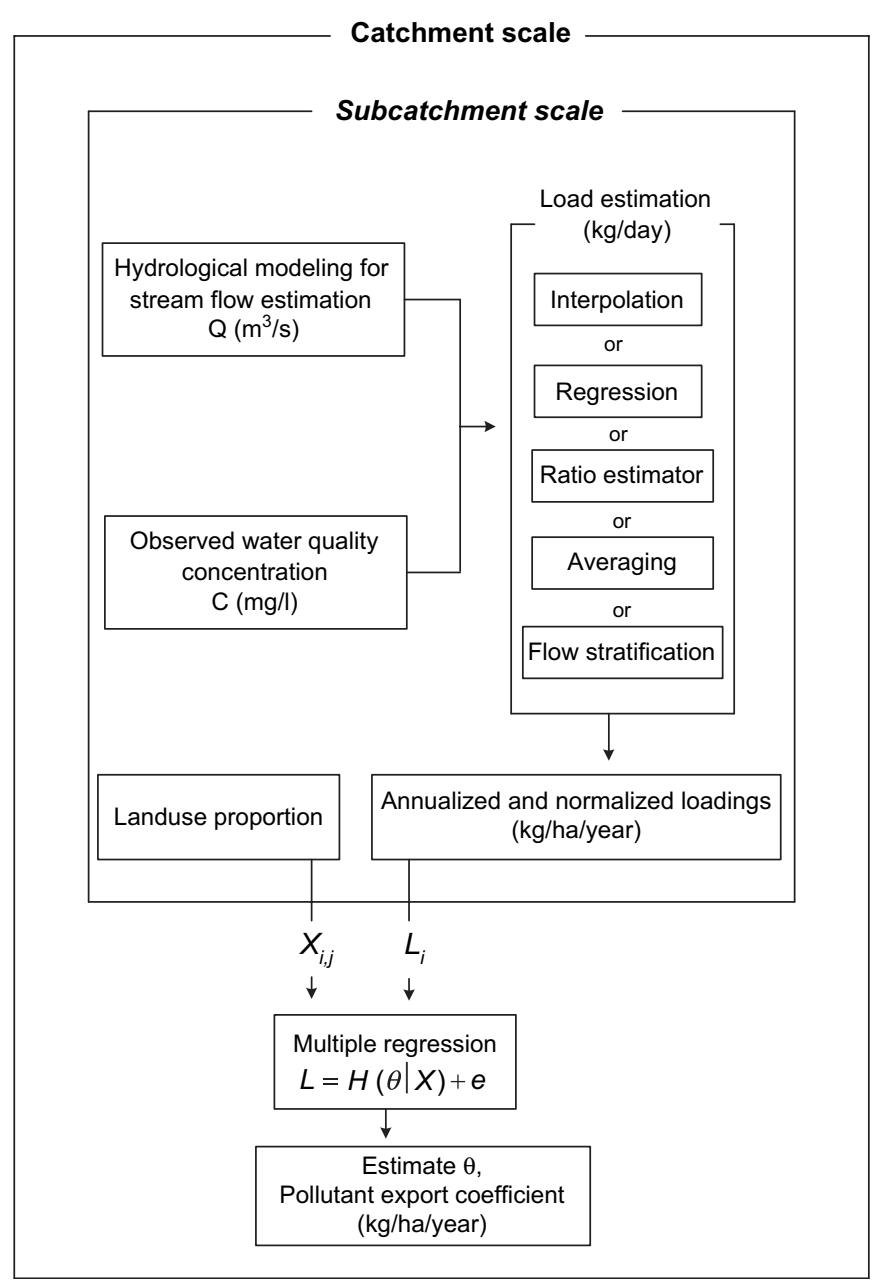

Fig. 1. General framework to estimate pollutant export coefficients from in-stream monitoring data, where $Q$ is the estimated flow, $C$ is the concentration, $H($.) is the functional relationship that relates annualized and normalized load with major landuse proportion, $\theta$ the parameter of $H($.$) is the pollutant export coefficient, X_{i, j}$ is the $j$ th proportion of landuse for $i$ th catchment.

\subsection{Catchment subdivision}

Catchments can be divided into sub-catchments by using Digital Elevation Model (DEM) data and readily available GIS software. Relatively high resolution and good quality global scale DEMs have become available in public domains. Some such DEMs are interpolated by improved interpolation methods and have been clipped around shorelines (http:// srtm.csi.cgiar.org/). A coarse resolution global DEM (GTOP30, $1 \mathrm{~km}$ ) is also available (ftp://edcftp.cr.usgs.gov/pub/data/ gtopo30/global/). This can be used to reduce the processing time during catchment division. The choice of the DEM resolution depends on the system availability and the accuracy needed to locate the water quality sampling stations in order to delineate sub-catchments.

\subsection{Determination of the major landuses and their areas}

It is widely recognized that landuse has significant impact on surface water quality. The proportion of major landuses above each monitoring site can be determined by overlaying the landuse map into drainage network generated using spatial tools viz. Geographic Information System (GIS). Land cover/landuse maps can often be obtained from government agencies or can be downloaded freely from public domains. The International Geosphere-Biosphere Programme (IGBP) has provided 17 classes of global land cover data for 1992-1993 (http://www.gnu.org/). Similarly, the European Commission Joint Research Centre (http://www.gvm.jrc.it/ glc2000) has provided 45 classes of global land cover data for 2000. However, if possible, locally available landuse information should be used. Since some of the landuse categories may be correlated for a single specific type of pollutant loading, Direct Gradient Analysis (DGA) (for e.g. Redundancy Analysis (RDA)) can be performed to determine the landuse categories which significantly contribute to a type of pollutant loading. RDA is a multivariate direct gradient analysis method in which species are presumed to have linear relationships with environmental gradients. In general, forest, agriculture, grassland and urban are the predominant landuse types which are significantly related to pollutant loadings. 


\subsection{Estimation of discharge at ungauged sites}

Accurate estimation of catchment water balance is a vital prerequisite for water quality modeling (Grayson et al., 1999). For this reason, hydrologic data, particularly streamflow, is a key data set enabling the catchment-scale modeling of water quality. Unfortunately, the measurement of streamflow is expensive, gauges are susceptible to failure, records are often short in length and data from these gauges are spatially fixed (Newham, 2002). Furthermore, it is uncommon that every water quality monitoring station is installed with discharge measuring equipment. Continuous observed streamflow is necessary to calculate pollutant loadings as it is a function of discharge and concentration. Therefore, this section aims to describe the appropriate method to estimate discharge at ungauged sites within a catchment. Several hydrological models have been developed to assist in understanding hydrologic behavior and improving water resources management in a river basin (Singh, 1995; Singh and Frevert, 2002a,b). According to the process description, these models can be classified into three categories: empirical (black box), conceptual and physics-based models. According to the spatial representation, the hydrological models are either lumped or distributed. Choice of a suitable model structure relies heavily on the functionality required by the model and availability of required data. Generally, the choice of model type depends on two main view points: emphasis on the processes at work or emphasis on the output (Merritt et al., 2003).

Empirical models are based on the analysis of observations and seek to characterize response from these data (Wheater et al., 1993). The computational and data requirements for such models are usually less than for conceptual and physics-based models, and are often supported by coarse measurements. Conceptual models are typically based on the representation of a catchment as a series of internal storages and tend to include a general description of catchment processes. They do not include the specific details of interaction between processes, which would require detailed catchment information (Sorooshian, 1991). Physics-based models are based on the solution of fundamental physical equations describing streamflow in a catchment. In theory, the parameters used in physics-based models are measurable and so are known. In practice, the large number of parameters involved and the heterogeneity of important characteristics, particularly in catchments, means that these parameters must often be calibrated against observed data (Wheater et al., 1993).

The predictive capability of empirical and conceptual models is questionable due to the semi-empirical nature of the process description (Thorsen et al., 2001). But there are some arguments that simple conceptual models, or empirical model, when used within the developed framework, can be more accurate than models with more complicated structures (Letcher et al., 1999a,b). Complex mechanistic models with large numbers of processes considered, and associated parameters, run the risk of having a high degree of uncertainty associated with the model inputs which are translated through to the model outputs. These uncertainties may negate the benefit of having a more realistic representation of the processes (Merritt et al., 2003).

Another issue in model choice is the area to which the model is applied. Of particular importance is whether the model considers processes and parameters to be lumped or distributed. The choice between lumped and distributed models depends on the desired output of the model and the nature of possible management interactions. However, it is important to recognize that some purposes, particularly increased understanding of the system and data, may be realized well even if the model is poor in many aspects (Jakeman et al., 2006). As mentioned earlier, an estimation of streamflow at ungauged sites at river catchment scale. Therefore, a distributed hydrological model with few parameters for calibration and which can simulate the streamflow at an ungauged site especially at catchment scales is required. There are a very few models available for estimating streamflow at river basin scale [e.g. OHyMoS (Ichikawa et al., 2000; Takasao et al., 1996), VIC (Liang et al., 1996), PRSM (Leavesley et al., 1983), BTOPMC (Ao, 2001; Takeuchi et al., 1999), DLRBM (Croley and He, 2005,2006), IHACRES (Croke and Jakeman, 2004; Croke et al., 2006; Jakeman and Hornberger, 1993; Merritt et al., 2005)].

\subsection{Estimation of pollutant loadings}

The load of a water-quality constituent in a stream i.e. the weight of material transported during specific time period is a function of the concentration of the constituent and the stream discharge. In general, load, $L$, over a time period $T$, can be represented by the equation

$L=\int_{0}^{T} C Q \mathrm{~d} t$

where $C$ is the constituent's concentration and $Q$ is the water discharge.

River discharge is usually sampled frequently, often at intervals of less than a day, and mostly continuously. Meanwhile, water quality constituents are generally sampled infrequently, often at routine intervals (i.e. daily, weekly, monthly or seasonally). In these cases, integrating concentration and streamflow may be inappropriate to calculate the loads. Calculating loads usually involves another method of estimating the concentration of constituents for the period within the sampling interval. There are many different techniques used for calculating load estimates, differing in complexity, accuracy and bias. The choice of technique may depend on the data resolution, the mathematical ability of the operator, the computer technology available, or the relationship within the data and between various constituents' concentrations (Letcher et al., 1999a,b). Existing methods for load estimation using field data can be classified into 
five classes: (i) interpolation techniques (Kronvang and Bruhn, 1996), (ii) averaging estimators which are based on a selection of available data (Dolan et al., 1981; Ferguson, 1987; Walling and Webb, 1981, 1988), (iii) ratio estimators (Beale, 1962; Preston et al., 1989), (iv) regression methods which use a regression relationship between $C$ and $Q$ (i.e. also called rating curve) to estimate unobserved concentration data (Ferguson, 1987; Koch and Smillie, 1986), and (v) stratification techniques. Reviews of methods of load estimation techniques using field data can be found in Preston et al (1989); Littlewood (1992); Littlewood et al (1998); Letcher et al (1999a,b); Mukhopadhyay and Smith (2000); Degens and Donohue (2002); Etchells et al. (2005) and Quilbe et al. (2006).

Based on the literature, Quilbe et al. (2006) suggest that: (i) averaging methods are accurate only when concentration measurements are available for the entire flow range; (ii) the ratio estimator is less sensitive to river and pollutant characteristics than regression methods but requires more data to achieve the same level of precision, and is robust and unbiased under systematic sampling, as well as under stratified event sampling; (iii) regression methods can give the best results for sediments and total $\mathrm{P}$ if streamflow and concentration data are strongly correlated for a wide range of streamflow values. Therefore, the regression method should be given priority if the correlation is good enough. The regression method does not require extensive data but the quality of prediction depends on the quality of the correlation between flows and concentrations (Smith and Croke, 2005). This requirement is often met for sediments, particulate and total $\mathrm{P}$, as well as pesticides, but more rarely for mobile chemicals such as nitrate or chlorides (Robertson and Roerish, 1999; Vieux and Moreda, 2003). Since the temporal variability of the relationship between concentration and streamflow can be very important (Haygarth et al., 2004), some authors proposed to define a regression equation as a function of time in order to take into account nonlinearities as well as seasonal and long-term variability (Cohn et al., 1989,1992,2005).

\subsection{Estimation of the pollutant export coefficients}

Typically, pollutant export coefficients are determined by monitoring landuses, such as forest, row crop or urban, using field plots to isolate individual landuses (Reckhow et al., 1980). Monitoring single landuse watershed may be ideal. Most watersheds (even small ones) are generally comprised of a variety of different landuses (McFarland and Hauck, 2001). Therefore, to isolate the loading contribution from the heterogeneous drainage areas, multiple regression techniques can be used to develop the pollutant export coefficients for the major landuses in the watershed based on procedures described by Hodge and Armstrong (1993) as described in eq. (2). The dependent variable is the pollutant loading and independent variables are landuse proportion in each sub-catchment. All multiple regression models can be developed using a forced zero intercept, thus, giving a loading of zero when all independent variables equal zero.

$A L_{i}=E C_{1} X_{i, 1}+E C_{2} X_{i, 2}+\ldots+E C_{n} X_{i, n}+\varepsilon_{i}$

where, $i=$ the individual sites used in the regression model; $A L_{i}=$ the annualized loading at site $i$ on a per hectare for the time period $(\mathrm{kg} / \mathrm{ha} / \mathrm{yr}) ; E C_{1}$ to $E C_{n}=$ the export coefficient for $n$ types landuses $(\mathrm{kg} / \mathrm{ha} / \mathrm{yr}) ; X_{i, 1}$ to $X_{i, n}=$ the fraction of land area above site $i$ represented by $n$ types of landuses and $\varepsilon_{i}=$ the random error associated with the difference between the measured and predicted loadings that is not explained by the model for site $i$.

\section{Development of pollutant export coefficients: a case study}

The methodology described in Section 2 is followed to develop the pollutant export coefficients for selected water quality constituents of the Fuji River catchment. Biochemical oxygen demand (BOD), chemical oxygen demand $\left(\mathrm{COD}_{\mathrm{Mn}}\right)$ nitrate nitrogen $\left(\mathrm{NO}_{3}-\mathrm{N}\right)$, and inorganic dissolved phosphorus $\left(\mathrm{PO}_{4}-\mathrm{P}\right)$ export coefficients are determined. These are considered the most important for management purposes in the Fuji River catchment.

The Fuji River catchment, drained by the Fuji River, is located in the central part of Japan (Fig. 2). The catchment area is $3,570 \mathrm{~km}^{2}$ and the mainstream length of the Fuji River is $128 \mathrm{~km}$. The river originates as the Kamanashi River, from Mount Komagatake in the north of the Southern Alps, and as the Fuefuki River from the north of Yamanashi Prefecture (region). These two rivers flow together in the south of the Kofu catchment as the Fuji River and subsequently, flow to the Pacific Ocean at Suruga Bay. The summers are hot and humid and winters are cold, with average daily temperatures of $26^{\circ} \mathrm{C}$ and $3{ }^{\circ} \mathrm{C}$, respectively. The catchment receives a mean annual precipitation of approximately $2100 \mathrm{~mm}$. The waters of the Fuji River catchment represent a valuable water resource contributing to the prefectural economic base through industrial, agricultural, recreational activities and hydropower operation. Nevertheless, the long term consequences of demands on the prefectural water resource remain unknown. Of particular concern is the response of waters to increasing non-point source pollutant loadings due to watershed development and landuse activities. Reductions in funding for monitoring have limited resources for current and future watershed diagnostic studies. No attempt has been made to review the existing data available from long term water quality monitoring and to investigate if catchment wide pollutant export coefficients can be developed.

Water quality data of biochemical oxygen demand (BOD), chemical oxygen demand $\left(\mathrm{COD}_{\mathrm{Mn}}\right)$, nitrate nitrogen $\left(\mathrm{NO}_{3}-\mathrm{N}\right)$ and inorganic dissolved phosphorus $\left(\mathrm{PO}_{4}-\mathrm{P}\right)$ was sampled semi-monthly to monthly at eight stations in the Fuji River catchment. Daily discharge at three stations during six years (1995-2000) were obtained from the Environment Division of Yamanashi Prefecture (EDYP) and Ministry of Land Infrastructure and Transportation (MLIT), respectively. 


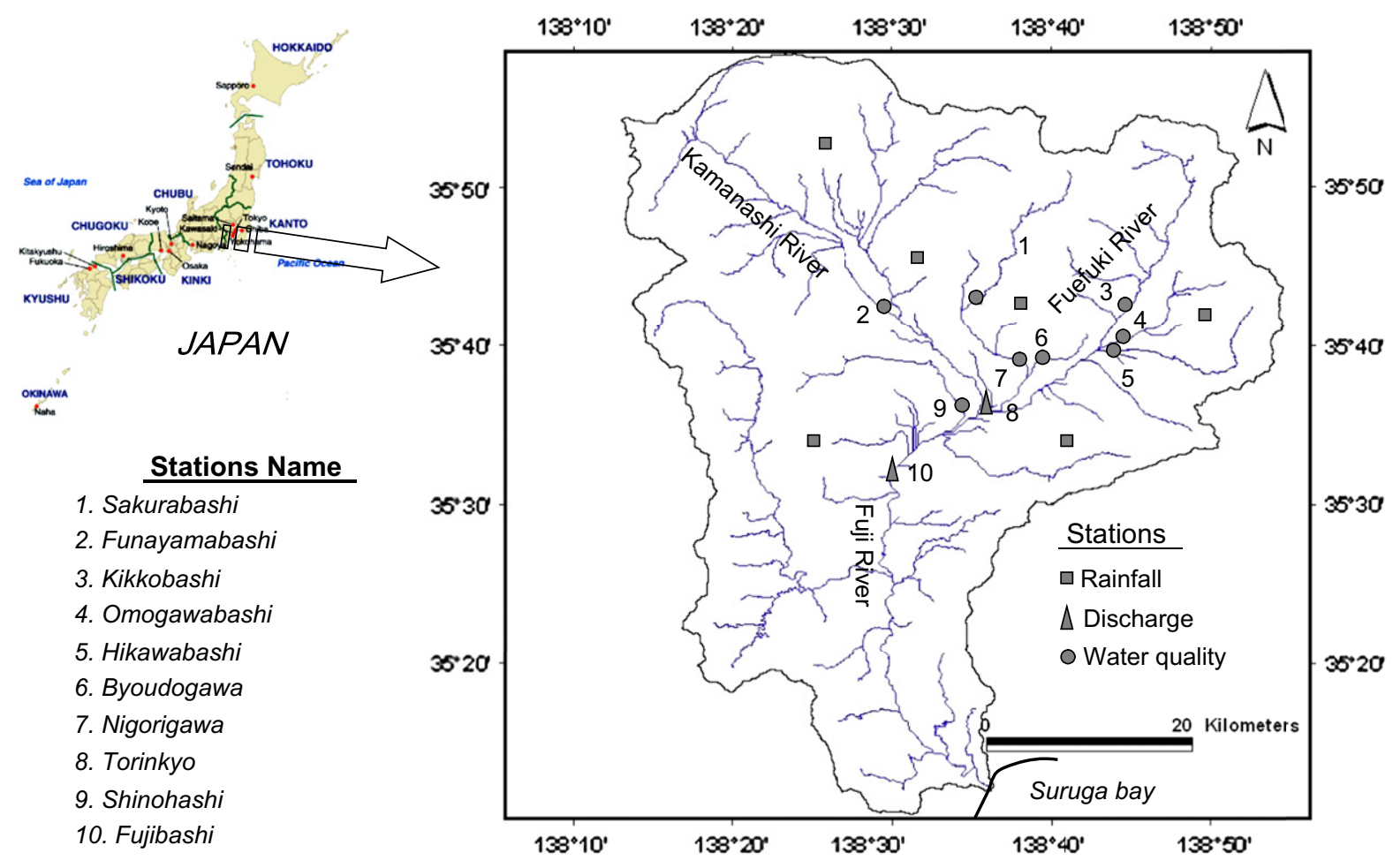

Fig. 2. Location map, rainfall, discharge and water quality monitoring stations in the Fiji River catchment.

\subsection{Determination of landuses above stream sampling sites}

A sub-catchment map defining drainage area for each sampling site was generated from a digital elevation model (250 m) using ArcGIS 8.3 and Arc Hydro tools according to water quality monitoring stations. Land cover map at 1:50,000 scale was overlaid and the proportion of major landuses in each sub-catchments were calculated. The size of the drainage area and percentage of major landuses above each sampling site are presented in Table 1. The landuse categories and their respective areas included in the classification are forest, agriculture, grassland and urban. In choosing the sampling sites, careful consideration was given to exclude sites which are heavily influenced by the major point sources in the catchments. Although some variations in landuse are expected to occur over time, the effects on the development of the pollutant export coefficients over the time period investigated was considered minimal.

\subsection{Estimation of discharge}

Of the eight sites considered, six lack streamflow records. In order to estimate the discharge at these ungauged sites, BTOPMC, a distributed hydrological model was used. The BTOPMC stands for "Blockwise use of TOPMODEL with Muskingum-Cunge routing". The BTOPMC is developed at University of Yamanashi (Japan) for hydrological simulations in large river basins (Ao et al., 2003; Takeuchi et al., 1999). To facilitate the application of the model to large river catchments, the total catchment area is subdivided into sub-catchments manually or automatically by the Pfafstetter numbering system (Verdin and Verdin, 1999). The three dimensional physiographic heterogeneity of the catchment is considered in the

Table 1

Landuses associated with the drainage area above sampling sites in Fuji River catchment

\begin{tabular}{|c|c|c|c|c|c|c|}
\hline Site & Forest $(\%)$ & Agriculture (\%) & Grassland (\%) & Urban (\%) & Other $(\%)$ & $\begin{array}{l}\text { Total area } \\
\left(\times 10^{3} \text { ha }\right)\end{array}$ \\
\hline Kikkobashi & 83.91 & 8.70 & 4.89 & 1.57 & 0.93 & 24.34 \\
\hline Hikawabashi & 78.27 & 12.72 & 4.59 & 2.86 & 1.55 & 11.11 \\
\hline Omogawabashi & 59.05 & 32.41 & 1.56 & 6.28 & 0.70 & 10.88 \\
\hline Sakurabashi & 82.75 & 9.58 & 2.78 & 0.85 & 4.04 & 15.50 \\
\hline Funayamabashi & 77.23 & 15.56 & 2.06 & 2.91 & 2.24 & 48.05 \\
\hline Shinohasi & 84.79 & 6.32 & 3.81 & 2.37 & 2.70 & 5.95 \\
\hline Nigorigawa & 4.62 & 66.07 & 1.82 & 27.08 & 0.41 & 1.57 \\
\hline Byoudogawa & 65.25 & 17.55 & 3.45 & 12.58 & 1.17 & 23.15 \\
\hline
\end{tabular}


model mutually in terms of topography, soil type, geology, vegetation cover, and rooting depth. The soil column is divided into three layers: root zone; unsaturated zone; and the saturated zone. The non-uniformity of the root zone depth over the catchment is taken into account using the distribution of land cover. In the model, runoff generation is based on the TOPMODEL (e.g. Beven and Binley, 1992; Beven and Kirkby, 1979; Quinn et al., 1995) concepts and flow routing is carried out using the Muskingum-Cunge method (Ao et al., 2003). The model parameters can be calibrated either manually or automatically using the Shuffle Complex Evolution (SCE-UA) algorithm (Duan et al., 1992). The input data to the model includes land cover, digital elevation model, soil, precipitation, and potential evaporation data. It is possible to obtain the hydrological characteristics (e.g., depth to the water table, actual evaporation, overland flow, base flow etc.) at any location (grid cell) of the catchment as model output. The BTOPMC exhibits the advantages of both lumped and distributed models. It has few parameters to be calibrated yet is capable of assessing the effects of landuse changes as well as water resource systems development. The model parameters have physical interpretability, representing the effects of topography, vegetation $\left(S r_{\max }\right)$, soil properties $\left(T_{0}\right.$, and $\left.m\right)$ and landuses $\left(n_{0}\right)$. This implies that BTOPMC can make use of GIS and remotely sensed spatial information of physical catchment characteristics without extensive ground observations, and has the potential to relate its parameters to catchment features. In addition, the hydrological response processes (spatial and temporal distribution of saturated areas) in a catchment can be easily visualized (Hapuarachchi et al., 2005). The BTOPMC consists of several sub-models viz. topographic sub model; runoff generation sub model; flow routing sub model. Further detail on the model's structure and parameter estimation procedure can be found in Ao et al (2003); Hapuarachchi et al (2004) and Takeuchi et al. (1999).

Rainfall and meteorological data of six stations, a digital elevation model, a landuse map and a soil map were used as input to the model. The hydro-meteorological data and digital elevation models were obtained from the Ministry of Land Infrastructure and Transport (MLIT); the landuse map was obtained from the Ministry of Environment and soil map was downloaded from the United Nations Food and Agriculture Organization's web site (http://www.fao.org/ag/agl/agll/ wrb/soilres.stm). The model calibration was carried out to optimize the model performance so that the differences between estimated and observed streamflow data could be minimized and better accuracy of model predictions accomplished. A detailed description on model calibration can be found in Shrestha and Kazama (2005). The whole catchment was divided into two sub-catchments (considered as blocks in BTOPMC). The sub-catchments were divided according to discharge station and covering the upstream site (Torinkyo) and downstream site (Fujibashi). The model was calibrated manually using the observed data for 1995-2000. The performance of the model was evaluated by Nash and Sutcliffe (NSE) efficiency and the ratio of simulated volume of discharge to observed volume of discharge $\left(Q_{\mathrm{sim}} / Q_{\mathrm{obv}}\right)$. The NSE is $70 \%$ and $75 \%$ for Fujibashi and Torinkyo stations respectively. Similarly, $Q_{\text {sim }} / Q_{\text {obv }}$ is more than $82 \%$ and $86 \%$ f for Fujibashi and Torinkyo stations respectively. In other words, model has slightly underestimated $(<20 \%)$ the volume of water which is considerable for loading estimation. The calibrated parameters with their definition are outlined in Table 2. The model is also very effective in simulating both the low flows and high flows. That is, the model captures the seasonal and annual variations in flow (Fig. 3). Therefore, the estimated flow at the six ungauged sites (Sakurabashi, Omogawabashi, Hikawabashi, Byodogawa, Nigorigawa and Shinohashi) was taken for the study. These all sites are located at the upstream of gauging sites which were for the calibration of parameters of BTOPMC.

\subsection{Estimation of pollutant loadings}

A seven-parameter log-linear model (Cohn et al., 1992) (eq. 3) was used to estimate loadings from each sub-catchment. Before applying this model, the correlation between streamflow and the concentration of biochemical oxygen demand, chemical oxygen demand, nitrate nitrogen and inorganic dissolved phosphorus was determined. The correlation

Table 2

Main controlling parameters of the BTOPMC model and their optimal calibrated values

\begin{tabular}{|c|c|c|c|c|}
\hline \multirow[t]{2}{*}{ Parameter } & \multirow[t]{2}{*}{ Dfinition eand units } & \multirow[t]{2}{*}{ Referable ranges $^{\mathrm{a}}$} & \multicolumn{2}{|l|}{ Optimal value } \\
\hline & & & Block I & Block II \\
\hline$m$ & $\begin{array}{l}\text { Decay factor of transmissivity: describes how the actual } \\
\text { transmissivity decreases when the soil is not saturated }(\mathrm{m})\end{array}$ & $0.001-0.3$ & 0.07 & 0.03 \\
\hline$n_{0}$ & $\begin{array}{l}\text { Roughness factor: a scaling parameter to compute Manning's } \\
\text { roughness for routing }\end{array}$ & $0.0001-0.4$ & 0.001 & 0.001 \\
\hline$S_{\text {rmax }}$ & $\begin{array}{l}\text { Maximum root zone capacity: represents the plant available } \\
\text { soil moisture capacity as well as interception capacity of the } \\
\text { canopy }(\mathrm{m})\end{array}$ & $0.001-0.015$ & $\begin{array}{l}\text { Deep rooted: } 0.03 \\
\text { Shallow rooted: } 0.02 \\
\text { Shallow rooted and irrigated: } 0.01 \\
\text { Impervious: } 0.0001\end{array}$ & \\
\hline$T_{0}$ & $\begin{array}{l}\text { Saturated soil transmissivity: describes the potential rate of } \\
\text { lateral flow for a completely saturated soil for a given hydraulic } \\
\text { gradient }\left(\mathrm{m}^{2} / \mathrm{h}\right)\end{array}$ & $0.1-100$ & $\begin{array}{l}\text { Clay: } 0.4 \\
\text { Sand: } 0.9 \\
\text { Silt: } 0.6\end{array}$ & \\
\hline
\end{tabular}

a Ao et al. (2006). 

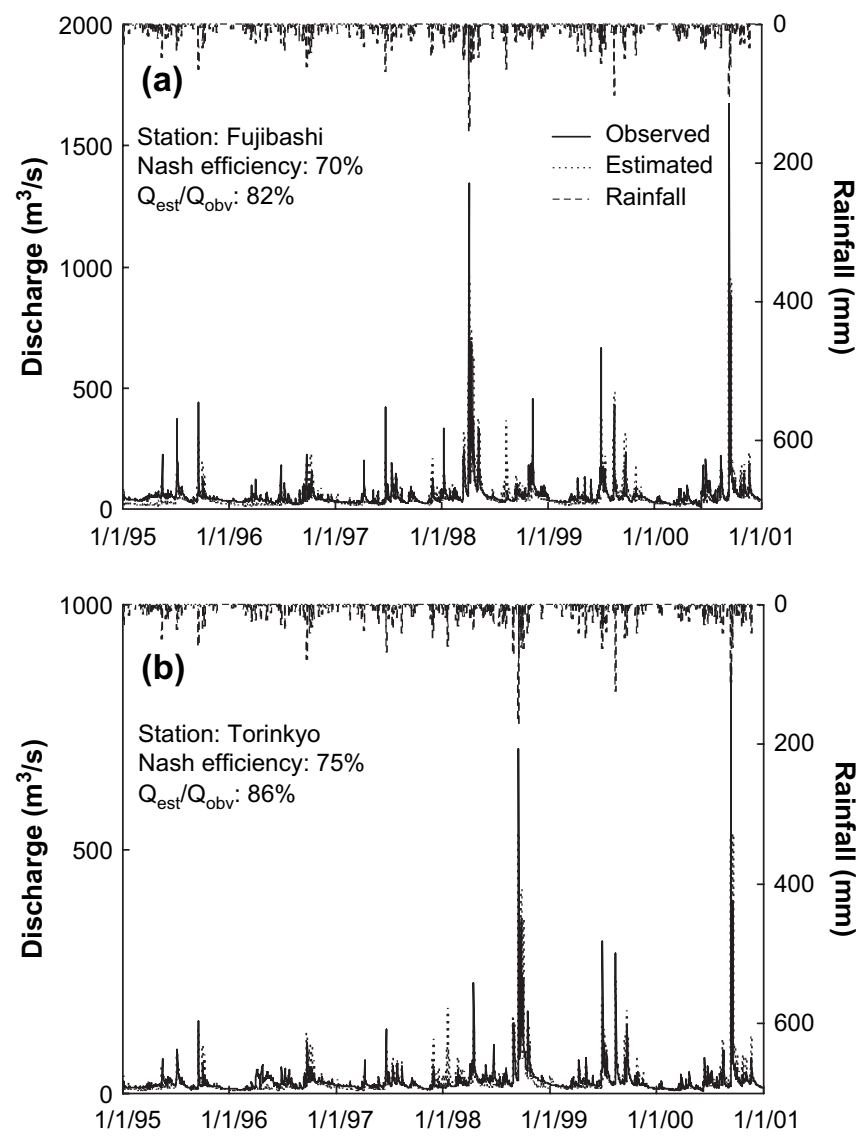

Fig. 3. Observed and estimated discharge at (a) Fujibashi and (b) Torinkyo during calibration.

was found to be greater than 0.6 in all cases. The model accounts the nonlinearities as well as seasonal and long-term variability while estimating loadings. It calculates loads of nutrients (and other constituents) carried by rivers employing a statistical regression model, where the constituent concentrations are estimated based on streamflow and time/season.

$$
\begin{aligned}
\ln [\mathrm{L}]= & \beta_{o}+\beta_{1} \ln \left[\frac{Q}{Q^{\prime}}\right]+\beta_{2}\left\{\ln \left[\frac{Q}{Q^{\prime}}\right]\right\}^{2}+\beta_{3}\left[T-T^{\prime}\right] \\
& +\beta_{4}\left[T-T^{\prime}\right]^{2}+\beta_{5} \sin [2 \pi T]+\beta_{6} \cos [2 \pi T]+\varepsilon
\end{aligned}
$$

where $\ln []$ denotes the natural logarithm function; $L$ is the estimated daily load (kg/day); $Q$ is the daily discharge $\left(\mathrm{ft}^{3} / \mathrm{s}\right)$; $T$ is time measured in years (converted to decimal form); $\beta_{0}$ is a constant; $\beta_{1}$ and $\beta_{2}$ describe the relation between concentration and discharge; $\beta_{3}$ and $\beta_{4}$ describe the trend in concentration data; $\beta_{5}$ and $\beta_{6}$ describe the seasonal variation in concentration data; $Q^{\prime}$ is a centering variable defined so that $\beta_{1}$ and $\beta_{2}$ are statistically independent; $T^{\prime}$ is a centering variable defined so that $\beta_{3}$ and $\beta_{4}$ are statistically independent; and $\varepsilon$ is the combined independent random error, assumed to be normally distributed with zero mean and variance $\sigma_{\varepsilon}^{2}$.

The model performs very well in estimating loadings. The coefficients of determination $\left(R^{2}\right)$ for loadings in all catchments are greater than $85 \%$. Fig. 4 shows a typical case of comparison between observed and estimated $\mathrm{NO}_{3}-\mathrm{N}$ loading from the two sub-catchments. The lack of fit in estimation was also tested by plotting probability plot correlation coefficient (PPCC) (Vogel, 1986) of the residuals, and found to be normally distributed. Similarly, residuals are plotted against the explanatory variables (as a typical case, Figs. 5 and 6) and against the predicted values (as a typical case, Figs. 7 and 8); they are reasonably homoscedastic. Loadings of each water quality constituent from each sub-catchment were annualized and normalized by the catchment area (Table 2) in order to set it as dependent variable in the multiple regression models. In turn, the pollutant export coefficients were derived.

\subsection{Determination of pollutant export coefficients of major landuses}

To isolate the loading contribution for each major landuse type from the heterogeneous drainage areas, multiple regression techniques were used to determine the organic matter/ nutrient export coefficients for the major landuses in the catchment based on procedures described by Hodge and Armstrong (1993). The dependent variables used were the annualized organic matter/nutrient loading (Table 3) and the independent variable used was landuse proportion in each sub-catchment. The results of multiple regression analysis are summarized in Table 4. Most of the coefficients for the landuse variables are significant at $\alpha$ equal to 0.05 and have coefficient of determination $\left(R^{2}\right)$ more than $85 \%$ for all regression models. This indicates that the landuse categories used as independent
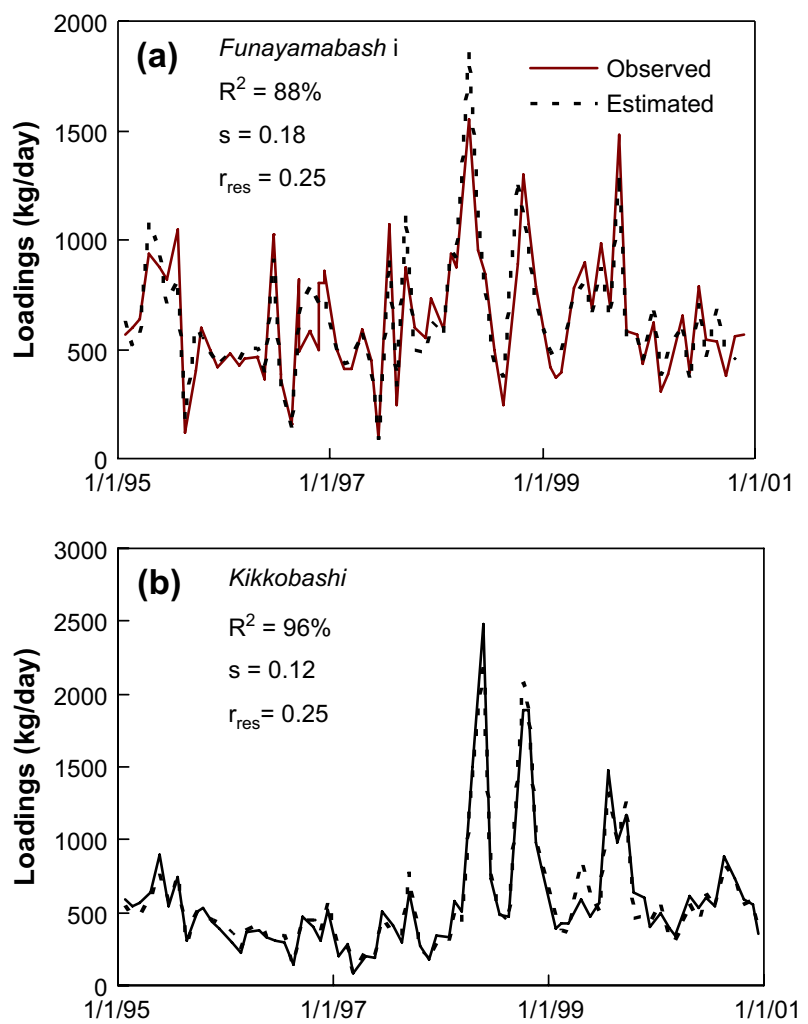

Fig. 4. Comparison between observed and estimated $\mathrm{NO}_{3}-\mathrm{N}$ loadings in (a) Kikkobashi and (b) Funayamabashi (as a typical case). 


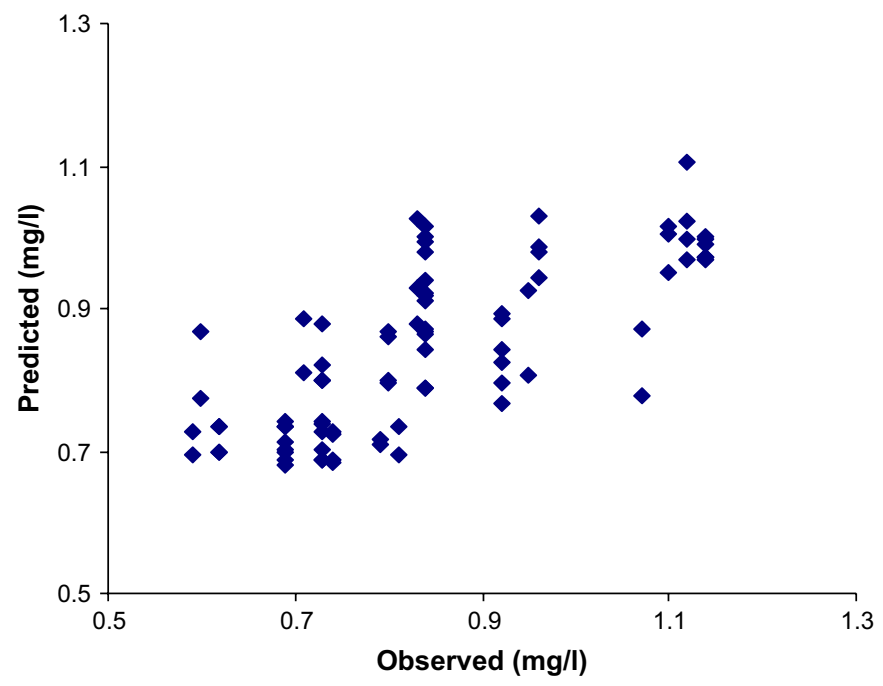

Fig. 5. Observed concentration of $\mathrm{NO}_{3}-\mathrm{N}$ plotted against predicted values for the Kikkobashi sub-catchment (as a typical case).

variables explain a large proportion of the variability in loadings. For forest landuse, not all the coefficients could be statistically defined as significantly different from zero. However, the positive values still represent the optimized coefficients for the current data set.

\section{Discussion}

A general framework has been described here to estimate pollutant export coefficients. It integrates GIS and Remote Sensing, hydrological modeling and statistical modeling. The pollutant export coefficients estimated from the developed methodology can be used for the catchment-scale modeling of pollutant loads into the water bodies. The framework addresses issues such as estimating the streamflow at ungauged sites, suitable methods of load estimation techniques according to the data availability. A distributed hydrological

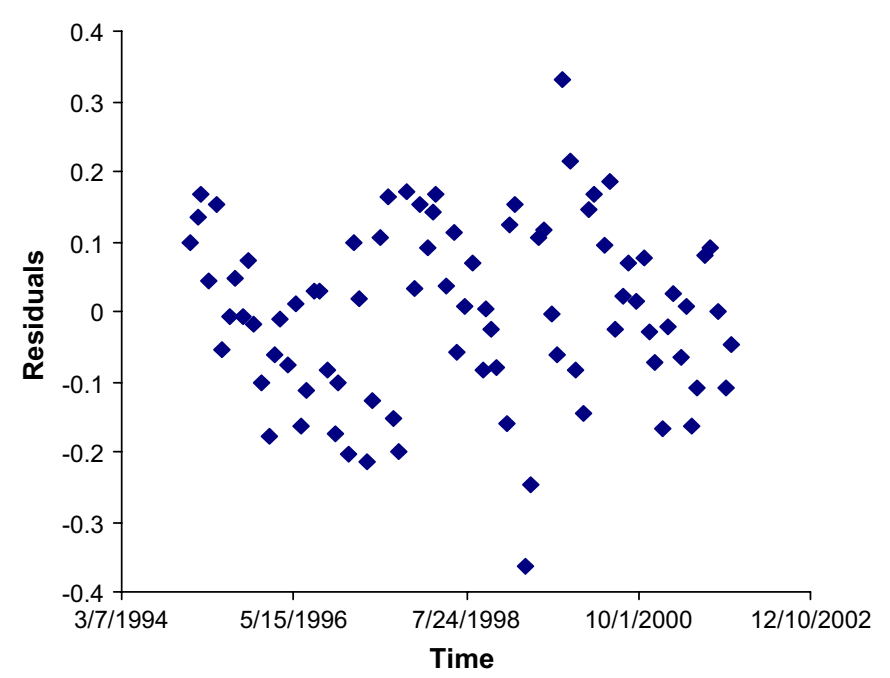

Fig. 6. Residual plotted against the time and $\mathrm{NO}_{3}-\mathrm{N}$ loading on six predictor variables for the Kikkobashi sub-catchment (as a typical case).

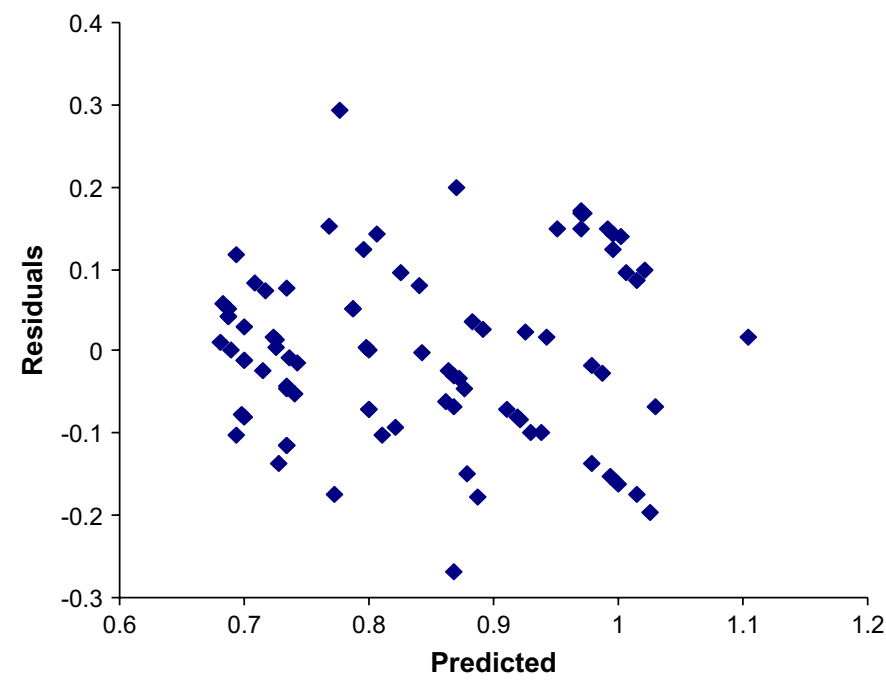

Fig. 7. Residual plotted against the predicted values from regression of $\mathrm{NO}_{3}-\mathrm{N}$ concentration on six predictor variables for the Kikkobashi sub-catchment (as a typical case).

modeling was proposed to account for the spatial variability in estimating streamflow at a river basin scale. Different suitable load estimation techniques were proposed according to the availability of streamflow and water quality constituent datasets. Similarly, multiple regression methodology was proposed to estimate optimal export coefficients from a catchment having heterogeneous landuse types.

The distributed hydrological model, BTOPMC, was applied to estimate flow at ungauged location as the model is relatively easy to calibrate; parsimoniously structured; has only four parameters for calibration; the input data requirements can be obtained from public domains. The model requires precipitation, streamflow, evapotranspiration, digital elevation model, land cover and soil map. Moreover, the BTOPMC has been applied over 30 river catchments of various scales and regions in the world using global GIS datasets [e.g.

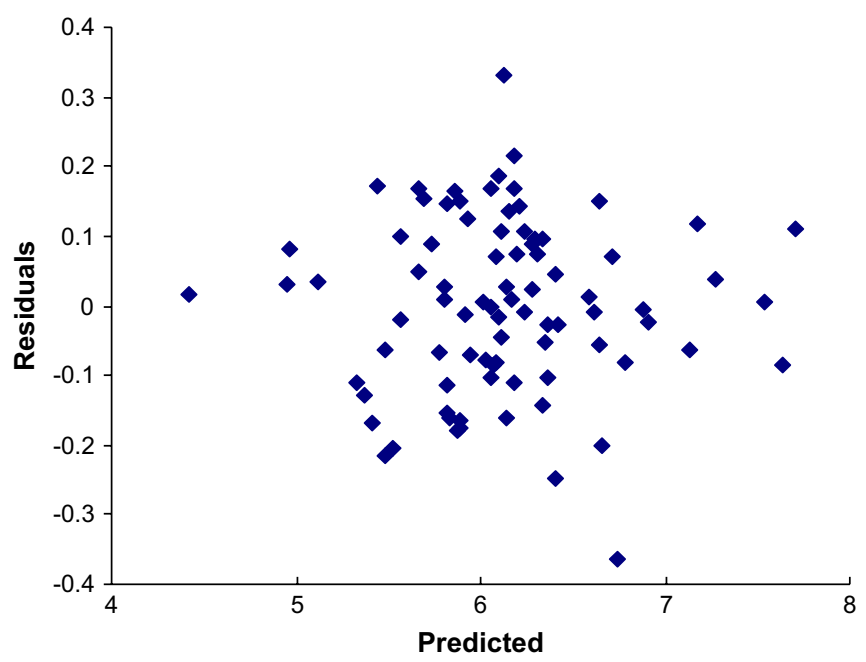

Fig. 8. Residual plotted against the predicted values from regression of $\mathrm{NO}_{3}-\mathrm{N}$ loading on six predictor variables for the Kikkobashi sub-catchment (as a typical case). 
Table 3

Estimated annualized and normalized organic matter and nutrient masses (kg/ ha/yr) associated with stream sampling sites in the Fuji River catchment for 1995-2000

\begin{tabular}{lrccc}
\hline Site & $\mathrm{BOD}$ & $\mathrm{COD}_{\mathrm{Mn}}$ & $\mathrm{NO}_{3}-\mathrm{N}$ & $\mathrm{PO}_{4}-\mathrm{P}$ \\
\hline Kikkobashi & 8.79 & 19.01 & 9.48 & 0.11 \\
Hikawabashi & 9.35 & 18.00 & n.a. & 1.01 \\
Omogawabashi & 22.56 & 36.97 & 14.80 & 0.45 \\
Sakurabashi & 2.57 & 12.47 & 1.91 & 0.05 \\
Funayamabashi & 6.23 & 7.43 & 5.47 & 0.21 \\
Shinohasi & 8.59 & 13.90 & 4.60 & 0.29 \\
Nigorigawa & 38.52 & 53.30 & 13.98 & 0.91 \\
Byoudogawa & 15.38 & 26.19 & 12.67 & 0.64 \\
\hline
\end{tabular}

n.a., not available.

GTOPO30 DEM (USGS), Digital Soil Map of the World (FAO)], satellite observations (ex. NDVI from Pathfinder AVHRR Land Data) and global meteorological data [e.g. Global Surface Summary of Day (NCDC/NOAA)] since most of the river catchments are poorly gauged. Through these applications, it was found that BTOPMC can simulate river discharge quite well in most warm humid regions (Ishidaira et al., 2005).

Among the various proposed load estimation techniques, the regression method was adopted to calculate the annual pollutant loads. However, the accuracy of estimation methods depends on several factors such as frequency of sampling, the length of the estimation period, the size of the watershed, the behavior of contaminants as well as human activities (e.g. landuse, tillage practices, fertilization etc.). The choice of the suitable method depends on the time, site and the strategy of sampling. The regression method used here does not require extensive data but the quality of estimation depends on the quality of correlation between streamflow and concentrations. In addition, the regression method requires the data sets which are sampled both in high flow and low flow conditions to capture the temporal variability in loadings. Given a larger amount of water quality data, the load estimates may be made more precise. In the case of a seven parameter log liner model, Cohn et al. (1992) suggested 25 water quality samples each year, half at high flow and half uniformly distributed over the course of the year (fortnightly sampling).

The averaging estimators can be used to estimate load by integrating the means of concentrations and streamflow over a time interval. However, if the data does not represent the

Table 4

Pollutant export coefficient $(\mathrm{kg} / \mathrm{ha} / \mathrm{yr})$ estimates for landuse variables based on the zero-intercept multiple regression model

\begin{tabular}{lllll}
\hline Landuse & $\mathrm{BOD}$ & $\mathrm{COD}_{\mathrm{Mn}}$ & $\mathrm{NO}_{3}-\mathrm{N}$ & $\mathrm{PO}_{4}-\mathrm{P}$ \\
\hline Forest & 1.00 & 0.75 & 2.12 & 0.71 \\
Agriculture & $0.62^{*}$ & $0.64^{*}$ & $1.06^{*}$ & $0.42^{*}$ \\
Grassland & $0.54^{*}$ & $0.52^{*}$ & $0.46^{*}$ & $0.59^{*}$ \\
Urban & $2.63^{*}$ & $1.48^{*}$ & $3.80^{*}$ & $1.73^{*}$ \\
$R^{2}$ & 0.96 & 0.97 & 0.89 & 0.85 \\
\hline
\end{tabular}

*Significant at $\alpha$ equal to $0.05 ; R^{2}$ is the variability explained by landuse categories on loadings in multiple regression models. entire range of streamflow and concentration values, it is necessary to estimate an accurate bias in load estimate (Ferguson, 1987). Similarly, averaging approaches tend to be biased if concentration is correlated with flow: the calculated load is too low if the correlation is positive and too high if the correlation is negative. Ratio estimators can be used as they are less sensitive to river and pollutant characteristics than regression methods but require more data to achieve the same level of precision (Preston et al., 1989). However, it is robust and unbiased only under systematic sampling as well as under stratified event sampling which is uncommon in commonly available in-stream monitoring datasets.

The multiple regression approach adopted in this study maximizes the use of in-stream monitoring data from stream sites with the mixed landuse drainage area within a monitoring network without the need for isolating individual landuse. In addition, the pollutant export coefficients estimated from the multiple regression approach represent the average conditions and practices of each of the landuses within a catchment. In the case study, although a very large number of data was used from a monitoring perspective, it still represents a relatively small dataset (8 sites) from a statistical perspective. In general, 30 or more sites are necessary to provide adequate power to the regression analysis approach of estimating pollutant export coefficients. However, the reliability of the pollutant export coefficients can be assessed explicitly by considering prior knowledge of typical values of pollutant export coefficients (derived from small catchment with a single dominating landuse category) and by performing a Bayesian, in addition to a frequentist, analysis (Zobrist and Reichert, 2006).

For the case study in the Fuji River Basin, most of the pollutant export coefficients are significant at $\alpha$ equal to 0.05 and the landuse categories used in the multiple regression models explained more than $85 \%$ variability in pollutant loadings. Furthermore, pollutant export coefficients from different studies within Japan have been reviewed and compared with the present study (Table 5). The wide variability in values available from literature reflects site specific variations in management and environmental conditions. Due to the unavailability of published nitrate nitrogen and inorganic dissolved phosphorus export coefficients, the derived coefficients were compared with published total nitrogen and total phosphorus export coefficients. The proportion of nitrate nitrogen to the total nitrogen and inorganic dissolved phosphorus to the total phosphorus are calculated from some less affected sites in the Fuji River catchment and it is found that total nitrogen contains more than $85 \%$ of nitrate nitrogen and total phosphorus contains more than $80 \%$ inorganic dissolved phosphorus. Therefore, it is assumed to be reasonable to compare the coefficients. The export coefficients of $\mathrm{NO}_{3}-\mathrm{N}$ for forest and urban landuse and $\mathrm{PO}_{4}-\mathrm{P}$ for forest and agriculture landuse agree with published values. Similarly, the export coefficients of $\mathrm{COD}_{\mathrm{Mn}}$ for forest and urban landuses are comparable with those available from literature.

The derived export coefficients of $\mathrm{NO}_{3}-\mathrm{N}$ and $\mathrm{COD}_{\mathrm{Mn}}$ for agriculture landuse are lesser and $\mathrm{PO}_{4}-\mathrm{P}$ for urban landuses is higher when compared with literature values. These 
Table 5

Range of available literature values of pollutant export coefficients $(\mathrm{kg} / \mathrm{ha} / \mathrm{yr})$ compared to estimated values for major landuses in the Fuji River catchment

\begin{tabular}{|c|c|c|c|c|c|c|}
\hline Landuse & $\mathrm{COD}_{\mathrm{Mn}}$ & $\mathrm{TN}$ & $\mathrm{NO}_{3}-\mathrm{N}$ & $\mathrm{TP}$ & $\mathrm{PO}_{4}-\mathrm{P}$ & Source \\
\hline \multirow[t]{2}{*}{ Forest } & 0.91 & $0.9-38.0$ & n.a. & $0.01-0.90$ & n.a. & Ukita and Nakanishi, 1999 \\
\hline & 0.75 & & 2.12 & & 0.71 & Present study \\
\hline Agriculture & 3.80 & $5.5-52.5$ & n.a. & 0.36 & n.a. & Ukita and Nakanishi, 1999 \\
\hline Urban & $\begin{array}{l}3.65 \\
1.48\end{array}$ & $5.3-6.9$ & $\begin{array}{l}\text { n.a. } \\
3.80\end{array}$ & 0.18 & $\begin{array}{l}\text { n.a. } \\
1.73\end{array}$ & $\begin{array}{l}\text { Ukita and Nakanishi, } 1999 \\
\text { Present study }\end{array}$ \\
\hline
\end{tabular}

n.a., not available.

differences can be attributed to the specific catchment characteristics for loading of these water quality constituents and the methodology used for deriving export coefficients. For example, a recent study conducted by Nakamura et al. (2005) shows that the $\mathrm{NO}_{3}-\mathrm{N}$ concentration, applied as fertilizers in agricultural areas, is higher in groundwater than in the river water of the Fuji River catchment. Therefore, a lower rate of nitrate loading is expected as compared to the actual field studies in other catchments. Similarly, in this study the concentration of $\mathrm{PO}_{4}-\mathrm{P}$ was influenced by the domestic wastewater discharge but the literature values do not account the influence of domestic wastewater. Therefore, a higher rate of $\mathrm{PO}_{4}-\mathrm{P}$ loading is expected as compared to the actual field studies in other catchments.

\section{Conclusions}

The pollutant export coefficients are very useful for estimating the total annual loads of pollution (organic matters and nutrients) to a waterbody from non-point sources and therefore serve as an important tool for identifying sources in the establishment of Total Maximum Daily Loads (TMDL) for an impaired watershed, particularly in circumstance where limited time and data is available for assessment. A framework is proposed to estimate the pollutant export coefficients using long-term in-stream water quality monitoring data set. The framework addresses the issues of estimating discharge at ungauged sites necessary to estimate loadings, suitable methods to estimate loadings and determine pollutant export coefficients from the catchments containing heterogeneous landuses. This methodology is simple to apply and leads to a result that can be used to find coarse estimates of the loads of the investigated compounds from poorly gauged or ungauged watersheds. The proposed framework was illustrated in a case study in which the pollutant export coefficients of organic matters (biochemical oxygen demand and chemical oxygen demand) and nutrients (nitrate nitrogen and inorganic dissolved phosphorus) in the Fuji River catchment were estimated. Most of the pollutant export coefficients are significant at $\alpha$ equal to 0.05 and the landuse categories used in the multiple regression models explained more than $85 \%$ variability in loadings. These export coefficients represents the average of conditions and practices (e.g., soils, slopes, tillage practices, fertilization timing and amounts etc). The pollutant export coefficients are compared with published values in order to evaluate their plausibility. Although the methodology in this study does not indicate the specific mechanisms causing surface runoff and pollutant transport, the derived coefficients can be used to estimate the non-point source pollution loadings from the major landuses particularly given the short time schedule and consequences of landuse changes to river water quality with limited data available.

\section{Acknowledgments}

We would like to extend sincere thanks to Yuki Hiraga for her help in the database development; Tim Cohn, Hazard Theme Coordinator of United Geological Survey (USGS), for providing a seven parameter log linear model; Satish Bastola for providing constructive criticism and valuable suggestions. We are also thankful to The Fuji Xerox Setsutaro Kobayashi Memorial Fund for providing funds and the 21st Century Center of Excellence (COE), University of Yamanashi for giving the opportunity to conduct this study.

\section{References}

Alexander, R.B., Elliott, A.H., Shankar, U., Mcbride, G.B., 2002. Estimating the source and transport of nutrients in the Waikato River Basin, New Zealand. Water Resources Research 38, 1268-1290.

Alp, M., Cigizoglu, H.K., 2007. Suspended sediment load simulation by two artificial neural network methods using hydrometeorological data. Environmental Modelling and Software 22 (1), 2-13.

Ao, T., 2001. Development of a distributed hydrological model for large river basins and its application to Southeast Asian rivers. Ph.D. thesis, Department of Civil and Environmental Engineering, University of Yamanashi.

Ao, T.Q., Takeuchi, T., Ishidaira, H., Yoshitani, J., Fukami, K., Matsuura, T., 2003. Development and application of a new algorithm for automated pits removal for grid DEMs. Hydrological Sciences Journal 48 (6), 985-997.

Ao, T.Q., Ishidaira, H., Takeuchi, T., Kiem, A.S., Yoshitani, J., Fukami, K., Magome, J., 2006. Relating BTOPMC model parameters to physical features of MOPEX basins. Journal of Hydrology 320, 84-102.

Arnold, J.G., Allen, P.M., 1996. Estimating hydrologic budgets for three Illinois watersheds. Journal of Hydrology 176, 57-77.

Beale, E.M.L., 1962. Some uses of computers in operational research. Industrielle Organization 31, 51-52.

Beasley, D.B., Huggins, L.F., Monke, E.J., 1980. ANSWERS: A model for watershed planning. Transaction of the ASAE 23 (4), 938-944.

Beaulac, M.N., Reckhow, K.H., 1982. An examination of landuse-nutrient export relationships. Water Resources Bulletin 18, 1013-1024.

Beven, K.J., Binley, A.M., 1992. The future of distributed models: model calibration and predictive uncertainty. Hydrological Processes 6, 279-298.

Beven, K.J., Kirkby, M.J., 1979. A physically based, variable contributing area model of hydrology. Hydrological Sciences Bulletin 24 (1), 43-69.

Carpenter, S.R., Caraco, N.F., Correll, D.L., Howarth, R.W., Sharpley, A.N., Smith, V.H., 1998. Nonpoint pollution on surface waters with phosphorus and nitrogen. Ecological Applications 8, 559-568. 
Cohn, T., DeLong, L.L., Gilroy, E.J., Hirsch, R.M., Wells, D.K., 1989. Estimating Constituent Loads. Water Resources Research 25 (5), 937-942.

Cohn, T., Caulder, D.L., Gilroy, E.J., Zynjuk, L.D., Summers, R.M., 1992. The Validity of a Simple Statistical Model for Estimating Fluvial Constituent Loads: An Empirical Study Involving Nutrient Loads Entering Chesapeake Bay. Water Resources Research 28 (9), 2353-2364.

Croke, B.F.W., Jakeman, A.J., 2004. A catchment moisture deficit module for the IHACRES rainfall-runoff model. Environmental Modelling and Software 19 (1), 1-5.

Croke, B.F.W., Andrews, F., Jakeman, A.J., Cuddy, S.M., Luddy, A., 2006. IHACRES Classic Plus: A redesign of the IHACRES rainfall-runoff model. Environmental Modelling and Software 21 (3), 426-427.

Croley II, T.E., He, C., 2005. Distributed-parameter large basin runoff model. I: Model development. Journal of Hydrologic Engineering 10 (3), 173-181.

Croley II, T.E., He, C., 2006. Watershed surface and subsurface spatial intraflows. Journal of Hydrologic Engineering 11 (1), 12-20.

Cuddy, S.M., Letcher, R., Croke, B., Saguantham, P., Saifuk, K., 2005. IWRAM DSS - a modelling approach for integrated water resources assessment and management in northern Thailand. In: Kachitvichyanukul, V., Purintrapiban, U., Utayopas, P. (Eds.), Proceedings of the 2005 International Conference on Simulation and Modelling, Bangkok, Thailand, 17-19 January 2005.

Degens, B.P., Donohue, R.D., 2002. Sampling mass loads in rivers: A review of approaches for identifying, evaluating and minimizing estimation errors. In: WRT25. Water and Rivers Commission, Perth.

Dolan, D., Yui, K., Geist, R., 1981. Evaluation of river load estimation methods for total phosphorus. Journal of Great Lakes Research 7, $207-$ 214.

Donigian, A.S., Bicknell, B.R., Imhoff, J.C., 1995. Hydrological simulation program-Fortran (HSPF). In: Singh, V.P. (Ed.), Computer Models of Watershed Hydrology. WRP, Highlands Ranch, CO, USA, pp. 395442.

Duan, Q., Sorooshian, S., Gupta, V.K., 1992. Effective and efficient global optimization for conceptual rainfall-runoff models. Water Resources Bulletin 28 (4), 1015-1031.

Etchells, T., Etchells, T., Tan, K.S., Fox, D., December 2005. Quantifying the uncertainty of nutrient load estimates in the Shepparton Irrigation Region. In: Zerger, A., Argent, R.M. (Eds.), MODSIM 2005 International Congress on Modelling and Simulation. Modelling and Simulation Society of Australia and New Zealand, ISBN 0-9758400-0-2, pp. 2665-2671. $<$ http://www.mssanz.org.au/modsim05/papers/etchells_2.pdf $>$.

Ferguson, R.I., 1987. Accuracy and precision of methods for estimating river loads. Earth Surface Processes and Landforms 12, 95-104.

Fisher, T.R., Lee, K.Y., Berndt, H., Benitez, J.A., Norton, M.M., 1998. Hydrology and chemistry of the Choptank river catchment. Water Air and Soil Pollution 105, 387-397.

Grayson, R.B., Argent, R.M., Western, A.W., 1999. Scoping study for the implementation of water quality management frameworks. CEAH report, for Department of Land and Water Conservation NSW, 53 pp.

Hapuarachchi, H.A.P., Magome, J., Struthers, I., Takeuchi, K. WinB TOPMC. University of Yamanashi, Kofu, Japan (in press).

Hapuarachchi, H.A.P., Kiem A.S., Takeuchi, K., Ishidaira, H., Magome, J., Tianque, A., 2005. Hydrological modeling and flood simulation of the Fuji River basin in Japan. In: Proceedings of the 7th International River Symposium, Brisbane, Australia.

Haygarth, P., Turner, B.L., Fraser, A., Jarvis, S., Harrod, T., Nash, D., Halliwell, D., Page, T., Beven, K., 2004. Temporal variability in phosphorus transfers: classifying concentration discharge event dynamics. Hydrology and Earth System Sciences 8 (1), 88-97.

Hodge, T.A., Armstrong, L.J., 1993. Use of a Multiple Linear Regression Model to Estimate Stormwater Pollutant Loading. In: James, W. (Ed.), New Techniques for Modelling the Management of Stormwater Quality Impacts. Lewis Publishers, Boca Raton, Florida, pp. 201-214.

Howarth, R., Anderson, D., Cloern, J., Elfring, C., Hopkinson, C., Lapointe, B., Malone, T., Marcus, N., McGlathery, K., Sharpley, A., Walker, D., 2000. Nutrient pollution of coastal rivers, bays, and seas. Issues Ecology 7, 1-16.
Ichikawa, Y., Shiiba, M., Tachikawa, Y., Takara, K., 2000. Object oriented hydrological modeling system. HydroInformatics CD-ROM, Cedar Rapids, Iowa.

ICWE, 1992. The Dublin Statement and report of the conference. International Conference on Water and the Environment: Development Issues.

Ishidaira, H., Takeuchi, K., Magome J., Hapuarachchi, P., Zhou, M., 2005. Application of distributed hydrological model YHyM to large river basins in Southeast Asia. In Proceedings of The Third International Symposium on Southeast Asian Water Environment, Bangkok, Thailand.

Jakeman, A.J., Hornberger, G.M., 1993. How much complexity is warranted in a rainfall-runoff model? Water Resources Research 29 (8), 2637-2649.

Jakeman, A.J., Letcher, R.A., Norton, J.P., 2006. Ten iterative steps in development and evaluation of environmental models. Environmental Modelling and Software 21 (5), 602-614.

Johnes, P.J., 1996. Evaluation and management of the impact of landuse change to the nitrogen and phosphorus load delivered to surface waters: the export coefficient modelling approach. Journal of Hydrology 183, 323-349.

Knisel, W.G., 1980. CREAMS, A field scale model for chemical, runoff and erosion from agricultural management systems, Conservation Report Number 26, US Department of Agriculture, Tucson, AZ.

Koch, R.W., Smillie, G.M., 1986. Bias in hydrologic prediction using logtransformed regression models. Water Resources Bulletin 22 (5), 717723 .

Kronvang, B., Bruhn, A.J., 1996. Choice of sampling strategy and estimation method for calculating nitrogen and phosphorus transport in small lowland streams. Hydrological Processes 10 (11), 1483-1501.

Leavesley, G.H., Lichty, R.W., Troutman, B.M., Saindon, L.G., 1983. Precipitation-Runoff Modeling System: User's Manual: U.S. Geological Survey Water-Resources Investigations Report 83-4238, 207 pp.

Leonard, R.A., Knisel, W.G., Still, D.A., 1987. GLEAMS: Groundwater loading effects of agricultural management systems. Transactions of ASAE 30 (5), 1403-1418.

Letcher, R.A., Jakeman, A.J., Merritt, W.S., McKee, L.J., Eyre, B.D., Baginska, B., 1999a. Review of Techniques to Estimate Catchment Exports. Environment Protection Authority, Sydney, South NSW 1232.

Letcher, R.A., Merritt, W.S., Jakeman, A.J., Braginska, B., 1999b. Modelling water quality in data poor catchments: a combined modelling approach, Proceedings of the International Congress on Modelling and Simulation (MODSIM99). New Zealand, vol. 1, 203-208.

Liang, X., Lettenmaier, D.P., Wood, E.F., 1996. A onedimensional statistical dynamic representation of subgrid spatial variability of precipitation in the two-layer variable infiltration capacity model. Journal of Geophysical Research 101 (D16), 403-421.

Littlewood, I.G., 1992. Estimating contaminant loads in rivers: a review. Report no. 117. Institute of Hydrology, Oxfordshire.

Littlewood, I.G., Watts, C.D., Custance, J.M., 1998. Systematic application of United Kingdom river flow and quality databases for estimating annual river mass loads (1975-1994. Science of the Total Environment 210-211, $21-40$.

Loehr, R.C., Ryding, S.O., Sonzogni, W.C., 1989. Estimating the nutrient load to a water body. In: Ryding, S.O., Rast, W. (Eds.), The Control of Eutrophication of Lakes and Reservoirs, Volume I. United Nations Educational Scientific and Cultural Organization, Paris, France and The Parthenon Publishing Group, Park Ridge, NJ, pp. 115-146. Man and the Biosphere Series.

Lophaven, S., Carstensen, J., Rootzen, H., 2006. Stochastic modelling of dissolved inorganic nitrogen in space and time. Ecological Modelling 193, 467-478

Matthies, M., Berlekamp, J., Lautenbach, S., Graf, N., Reimer, S., 2006. System analysis of water quality management for the Elbe river basin. Environmental Modelling and Software 21 (9), 1309-1318.

McFarland, A.M.S., Hauck, L.M., 2001. Determining nutrient export coefficients and source loading uncertainty using in-stream monitoring data. Journal of the American Water Resource Association 37 (1), 223-236.

Merritt, W.S., Letcher, R.A., Jakeman, A.J., 2003. A review of erosion and sediment transport models. Environmental Modelling and Software 18, $761-799$ 
Merritt, W.S., Croke, B.F.W., Jakeman, A.J., 2005. Sensitivity testing of a model for exploring water resources utilisation and management options. Environmental Modelling and Software 20 (8), 1013-1030.

Mukhopadhyay, B., Smith, E.H., 2000. Comparison of statistical methods for estimation of nutrient load to surface reservoirs for sparse data set: application with a modified model for phosphorus availability. Water Research 34 (12), 3258-3268.

Nakamura, T., Shrestha, S., Satake, H., Kazama, F., 2005. Tracing nitrate transport in the ground-water aquifers using isotope techniques-a case study in Western Kofu Catchment, Japan, in: Proceedings of the Third International Symposium on Southeast Asian Water Environment, Bangkok, Thailand.

Newham, L.T.H., 2002. Catchment scale modelling of water quality and quantity. PhD Thesis, The Australian National University, Australia.

Newham, L.T.H., Letcher, R.A., Jakeman, A.J., Kobayashi, T., 2004. A framework for integrated hydrologic, sediment and nutrient export modeling for catchment-scale management. Environmental Modelling and Software 19, 1029-1038.

Novotny, V., 1999. Integrating diffuse/nonpoint pollution control and water body restoration into watershed management. Journal of the American Water Resources Association 35 (4), 717-727.

Novotny, V., 2003. Water Quality Diffuse Pollution and Watershed Management, second ed. John Wiley and Sons, USA. 719-779.

Polyakov, V., Fares, A., Kubo, D., Jacobi, J., Smith, C., in press. Evaluation of a non-point source pollution model, AnnAGNPS, in a tropical watershed. Environmental Modelling and Software. Available online 19 January 2007.

Preston, S.D., Bierman, V.J., Silliman, S.E., 1989. An evaluation of methods for the estimation of tributary mass loads. Water Resources Research 25 (6), 1379-1389.

Quilbe, R., Rousseau, A.N., Duchemin, M., Poulin, A., Gangbazo, G., Villeneuve, J.P., 2006. Selecting a calculation method to estimate sediment and nutrient loads in streams: Application to the Beaurivage River (Quebec, Canada). Journal of Hydrology 326 (1-4), 295-310.

Quinn, P.F., Beven, K.J., Lamb, R., 1995. The $\ln (\mathrm{a} / \mathrm{tanâ})$ index: how to calculate it and how to use it in the TOPMODEL framework. Hydrological Processes 9, 161-182.

Rast, W., Lee, G.F., 1983. Nutrient loading estimates for lakes. Journal of Environmental Engineering 109, 502-517.

Reckhow, K.H., Beaulac, M.N., Simpson, J.T., June 1980. Modeling phosphorus loading and lake response under uncertainty: A manual and compilation of export coefficients. U.S. Environmental Protection Agency, Clean Lake Section, Washington, D.C, EPA 440/5-80-011, 214 pp.

Robertson, D.M., Roerish, E.D., 1999. Influence of various water quality sampling strategies on load estimates for small streams. Water Resources Research 35, 3747-3759.

Santhi, C., Srinivasan, R., Arnold, J.G., Williams, J.R., 2006. A modeling approach to evaluate the impacts of water quality management plans implemented in a watershed in Texas. Environmental Modelling and Software 21 (8), 1141-1157.

Shen, J., Parker, A., Riverson, J., 2005. A new approach for a windows-based watershed modeling system based on a database-supporting architecture. Environmental Modelling and Software 20, 1127-1138.

Shrestha, S., Kazama, F., 2005. Development of landuse export coefficients for the estimation of nutrient loads in Fuji river basin, Japan, in: Proceedings of the 14th Korea/Japan Symposium on Water Environment, Masan, South Korea.

Shrestha, S., Babel, M.S., Das Gupta, A., Kazama, F., 2006. Evaluation of annualized agricultural non point source model for a watershed in the Siwalik Hills of Nepal. Environmental Modelling and Software 21 (7), 961-975.

Singh, V.P., 1995. In: Computer Models of Watershed Hydrology. Water Resources Publication, USA, 1145 pp.
Singh, V.P., Frevert, D.K., 2002a. In: Mathematical Models of Large Watershed Hydrology. Water Resources Publications, LLC, Highlands Ranch, CO, USA, p. 891.

Singh, V.P., Frevert, D.K., 2002b. In: Mathematical Models of Small Watershed Hydrology and Applications. Water Resources Publications, LLC, Highlands Ranch, CO, USA, p. 950.

Smith, C.J., Croke, B.F., 2005. Sources of uncertainty in estimating suspended sediment load. Proceedings of symposium S1 held during the seventh IAHS Scientific Assembly, Foz do Igaussu, Brazil, 3-9 April 2005, pp. 136-143.

Sorooshian, S., 1991. Parameter estimation, model identification, and model validation: conceptual-type models. In: Bowles, D.S., O'Connell, P.E. (Eds.), Recent Advances in the Modelling of Hydrologic Systems. Series 345. NATO ASI, pp. 443-467.

Takasao, T., Shiiba, M., Ichikawa, Y., 1996. A runoff simulation with structural hydrological modeling system. Journal of Hydroscience and Hydraulic Engineering. JSCE 14 (2), 47-55.

Takeuchi, K., Ao, T.Q., Ishidaira, H., 1999. Introduction of block-wise use of TOPMODEL and Muskingum-Cunge method for the hydro-environmental simulation of a large ungauged basin. Hydrological Sciences Journal 44, 633-646.

Thorsen, M., Refsgaard, J.C., Hansen, S., Pebesma, E.J., Jensen, J.B., Kleeschulte, S., 2001. Assessment of uncertainty in simulation of nitrate leaching to aquifers at catchment scale. Journal of Hydrology 242, 210-227.

Ukita, M., Nakanishi, H., 1999. Pollutant load analysis for the environmental management of enclosed sea in Japan, in: Proceedings of the Fourth International Conference on the Management of Enclosed Coastal Seas.

Verdin, K.L., Verdin, J.P., 1999. A topographical system for delineation and codification of the Earth's river basins. Journal of Hydrology 218, $1-12$.

Vieux, B.E., Moreda, F.G., 2003. Nutrient loading assessment in the Illinois River using a synthetic approach. Journal of the American Water Resources Association 39 (4), 757-769.

Vogel, R.M., 1986. The probability plots correlation coefficient tests for the normal, lognormal, and Gumbel distributional hypotheses. Water Resource Research 22 (4), 587-590.

Walling, D.E., Webb, B.W., 1981. The reliability of suspended sediment load data, erosion and sediment transport measurement, in: Proceedings of the Florence Symposium, IAHS Publication no. 133, pp. 177-194.

Walling, D.E., Webb, B.W., 1988. The reliability of rating curve estimates of suspended yield: some further comments, sediment budgets, in: Proceedings of the Porto Alegre Symposium, IAHS Publication no. 174, pp. 337-350.

Wheater, H.S., Jakeman, A.J., Beven, K.J., 1993. Progress and directions in rainfall-run-off modeling. In: Jakeman, A.J., Beck, M.B., McAleer, M.J. (Eds.), Modeling Change in Environmental Systems. Wiley, New York, pp. 101-132.

Wickham, J.D., Wade, T.G., Riitters, K.H., O’Neill, R.V., Smith, J.H., Smith, E.R., Jones, K.B., Neale, A.C., 2003. Upstream-to-downstream changes in nutrient export risk. Landscape Ecology 18, 195-208.

Yeh, S., Wang, C., Hui-Ching Yu, H., 2006. Simulation of soil erosion and nutrient impact using an integrated system dynamics model in a watershed in Taiwan. Environmental Modelling and Software 21 (7), 937-948.

Young, R.A., Onstad, C.A., Bosch, D.D., Anderson, W.P., 1989. Agricultural non-point source pollution model for evaluating agricultural watersheds. Journal of Soil and Water Conservation 44 (2), 168-173.

Yuan, D., Lin, B., Falconer, R.A., Tao, J., 2007. Development of an integrated model for assessing the impact of diffuse and point source pollution on coastal waters. Environmental Modelling and Software 22 (6), 871-879.

Zobrist, J., Reichert, P., 2006. Bayesian estimation of export coefficients from diffuse and point sources in Swiss watersheds. Journal of Hydrology 329 (1-2), 207-223. 